\title{
Anaphylaxis and Clinical Utility of Real World Measurement of Acute Serum Tryptase in UK Emergency Departments
}

\author{
Short title: Tryptase Measurement in the Emergency Department
}

\section{Richard J. Buka ${ }^{1,2}$ MBChB, Rebecca C. Knibb ${ }^{3}$ PhD, Richard J. Crossman ${ }^{4}$ \\ PhD, Cathryn L. Melchior ${ }^{1}$ RN, Aarnoud P. Huissoon ${ }^{1}$ PhD FRCP, Scott \\ Hackett $^{5}$ MD FRCPCH, Susan Dorrian ${ }^{6}$ FRCP, Matthew W. Cooke ${ }^{6}$ PhD \\ FRCS, Mamidipudi T. Krishna ${ }^{1,7}$ PhD FRCP}

\footnotetext{
${ }^{1}$ Department of Allergy and Immunology, Heart of England NHS Foundation Trust, Birmingham, UK

${ }^{2}$ Institute of Inflammation \& Ageing, University of Birmingham, UK

${ }^{3}$ Department of Psychology, Aston University, Birmingham, UK

${ }^{4}$ University of Warwick, Warwick, UK

${ }^{5}$ Department of Pediatric Allergy, Immunology and Infectious Diseases, Heart of England NHS Foundation Trust, Birmingham, UK

${ }^{6}$ Department of Emergency Medicine, Heart of England NHS Foundation Trust, Birmingham, UK

${ }^{7}$ Institute of Immunology \& Immunotherapy, University of Birmingham, UK
}

\section{Address for correspondence}

Dr. RJ Buka

Department of Allergy and Clinical Immunology

Heart of England NHS Foundation Trust

Birmingham

B9 5SS

United Kingdom

Email: r.j.buka@bham.ac.uk

Tel: 00441214241908

Fax: 00441214243229

\section{Funding source}

This work had no external funding source

\section{Word count}

4124 (main body of text excluding title page, abstract, keywords figures, legends, tables and references). 


\section{Abstract}

\section{Background:}

42 British guidelines recommend that serial acute serum tryptase (acute serum tryptase) measurements are checked in all adults and a subset of children presenting with anaphylaxis. This is the first study reporting the clinical utility of acute serum tryptase in a 'real world' emergency department (ED) setting following the publication of the World Allergy Organization criteria for anaphylaxis.

46 Aims: To (a) assess sensitivity, specificity, positive and negative predictive values (PPV, NPV) of acute

47 serum tryptase in anaphylaxis (b) determine factors associated with higher acute serum tryptase levels and (c) audit compliance of acute serum tryptase measurement in the EDs.

Methods: Retrospective electronic search for ED admissions to three acute care hospitals in

Birmingham, UK with anaphylaxis in 2012 using wide search terms followed by scrutiny of electronic clinical records and application of the WAO diagnostic criteria for anaphylaxis. Patients with an acute serum tryptase measurement were included in the analysis.

Results: Acute serum tryptase was measured in 141 of 426 (33.1\%) cases. Mean time from the onset of symptoms to the measurement of acute serum tryptase was 4 hours 42 minutes ( $\mathrm{SD} \pm$ 05:03 hours) and no patients had serial measurements conforming to British guidelines. Acute serum tryptase $>12.4$ $\mathrm{ng} / \mathrm{ml}\left(75^{\text {th }}\right.$ centile) was associated with a sensitivity, specificity, PPV and NPV of $28 \%, 88 \%, 0.93$ and

570.17 respectively. Multiple regression analysis showed that male sex $(\mathrm{OR}=2.66[\mathrm{p}=0.003])$ and 58 hypotension $(\mathrm{OR}=7.08[\mathrm{p}=0.001])$ predicted higher acute serum tryptase.

\section{Conclusion:}

60 An acute serum tryptase $>12.4 \mathrm{ng} / \mathrm{ml}$ in an ED setting carries high PPV and specificity, but poor 61 sensitivity and NPV. 


\section{Key words}

63 Anaphylaxis

64 Emergency Department

65 Hypotension

66 Tryptase

67 ROC curve

68

69 Abbreviations

70 CI - Confidence Interval

$71 \mathrm{df}$ - Degrees of Freedom

72 ED - Emergency Department

$73 \mathrm{ng} / \mathrm{ml}$ - Nanograms per Milliliter

74 NHS - National Health Service

75 NPV - Negative Predictive Value

76 OR - Odds Ratio

77 PPV - Positive Predictive Value

78 ROC - Receiver Operator Characteristic

79 SD - Standard Deviation

80 UK - United Kingdom

81 WAO - World Allergy Organization 


\section{Highlights}

83

84 What is already known about this topic?

85 Acute serum tryptase can be raised in anaphylaxis and current British guidelines recommend serial

86 measurements. Sensitivity and specificity is published from the controlled environment of allergen

87 challenge but not from the emergency department.

88 What does this article add to our knowledge?

89 This British study is the first to document the sensitivity, specificity, positive and negative predictive

90 value of acute serum tryptase in emergency department anaphylaxis. Acute serum tryptase $>12.4 \mathrm{ng} / \mathrm{ml}$

91 carries a high positive predictive value and specificity but poor sensitivity.

92 How does this study impact current management guidelines?

93 Optimal real world sampling of acute serum tryptase is difficult and acute serum tryptase is a poor

94 biomarker for anaphylaxis. However, acute serum tryptase is useful in some situations to differentiate

95 anaphylaxis from its mimics and should remain part of anaphylaxis assessment. 
96

97

\section{Introduction}

Tryptase is a serine protease released from mast cells during an acute allergic reaction. Acute serum tryptase measurement is advised in the evaluation of patients with anaphylaxis. (1-2) British guidelines explicitly recommend that serial blood samples for acute serum tryptase should be taken as soon as possible after the onset of symptoms, at 1-2 hours following symptom onset and a baseline sample at least 24 hours after the episode. (1) These timings reflect the half-life of tryptase which is approximately two hours with levels peaking 1-2 hours after onset and usually returning to baseline within 6-8 hours. (3-4) The results are not immediately available to the emergency physician and therefore are not part of the initial evaluation but are used later in the follow-up of these patients at an allergy clinic.

The role for biomarkers of anaphylaxis, acute serum tryptase in particular, is unclear especially as seemingly severe episodes of anaphylaxis may not be associated with an elevated level $(3,5)$ and viceversa. Furthermore, there are currently no agreed international criteria for interpretation of acute serum tryptase in anaphylaxis with respect to a 'cut off' or a percentage change from a baseline measurement, although $\geq 11.4 \mathrm{ng} / \mathrm{ml}$ is frequently cited. Given that anaphylaxis in the community is nearly always an unpredictable event and is dealt with almost exclusively by emergency care providers, we felt it important to investigate acute serum tryptase in this group of patients. Previous studies investigating the utility of acute serum tryptase in an ED setting have involved prospective recruitment of patients with relatively small sample sizes, used different 'cut off' levels for interpretation and were carried out prior to publication of the World Allergy Organization (WAO) diagnostic criteria for anaphylaxis which now provide us with a unified, agreed definition of anaphylaxis. Moreover, they did not report sensitivity, specificity, positive predictive value (PPV) and negative predictive value (NPV). (3,5-7) Our study is therefore an attempt to evaluate the performance of acute serum tryptase in a 'real world' setting.

We have recently published epidemiological data on 426 cases of anaphylaxis presenting to three EDs in Birmingham, UK in 2012. (8) Here, we present further data analysis of a subgroup of patients from the same cohort who had a measurement of acute serum tryptase when they attended the ED. The main objectives of the study were to: (a) assess sensitivity, specificity, PPV and NPV of acute serum tryptase 
124 and (c) audit compliance of acute serum tryptase measurement as per British guidelines. 
127 This is a retrospective, observational study of patients attending three busy EDs (total admissions in 2012 - 251,215) with anaphylaxis/suspected anaphylaxis in one of the largest National Health Service (NHS) organizations in the UK (Heart of England NHS Foundation Trust [HEFT]). The catchment area of the three hospitals in the organization includes East and North Birmingham, Solihull and South Staffordshire, a population of over 890,000 people.

\section{Patients}

All ED attendances are coded using an 'in-house' coding system. We carried out an electronic search of the database of ED attendances using a number of wide-reaching search terms to cover allergic presentations and retrieved 3516 potential cases of anaphylaxis. The search terms were: 'Allergic Reaction', 'Anaphylactic Shock', 'Anaphylaxis', ‘Angioedema', 'Bite - Insect Non Venom', 'Bite Insect Venom', 'Skin - Allergic Reaction', 'Skin - Rash, Other' and 'Skin - Urticaria'.

Next, one clinician scrutinized the scanned ED documentation, ambulance sheet, and other electronic information including clinic records where available. Through retrospective application of the WAO diagnostic criteria for anaphylaxis (9) to patients' presenting symptoms, cases of anaphylaxis were identified and data extracted. When possible, anaphylaxis mimics such as asthma and hereditary angioedema, among others, were excluded.

We also identified a small control group of patients (for constructing receiver operating characteristic [ROC] curves) who presented to the ED with allergic symptoms in whom acute serum tryptase measurement was requested by the admitting physician, but did not fulfill the WAO diagnostic criteria for anaphylaxis.

In order to ensure the quality and reproducibility of the data extraction, initial data collection from a number of case notes was jointly performed by two clinicians in order to ensure appropriate inclusion and exclusion of cases and to improve consistency. Following this, when there was uncertainty from the first clinician about inclusion or exclusion of potential cases, these cases were jointly reviewed and discussed with the second clinician at weekly meetings during the data collection phase. When halfway 
through the data collection period, every previously assessed case was reassessed in order to eliminate bias associated with learned experience. In this reassessment, there were no cases that had been erroneously included however several had been missed and these were therefore incorporated into the dataset.

Basic demographic data including age, sex, address and ethnicity, is available for every patient from the hospital database. Demographic data and data pertaining to symptoms (including time of onset) and co-morbidities were extracted from the case records of every attendance that fulfilled the inclusion criteria using a standardized proforma and recorded in a spreadsheet (Microsoft Excel [2007]). Entries were coded and checked twice by one clinician. Additionally, where patients had been reviewed by an allergy specialist, clinic records were analyzed to identify causative factors. As per the hospital policy, all cases of anaphylaxis and suspected anaphylaxis should be referred to the allergy clinic following discharge from the emergency department. An appointment is offered for allergy specialist review with 18 weeks from the date of referral (with an option of an urgent appointment in specific cases). Cases were assigned a severity grading according to the 'Brown grading system'. (10) acute serum tryptase measurement including the timing of samples, recorded on the electronic hospital database system, was extracted from the electronic system including the timing of the sample. Laboratory serum tryptase analysis was undertaken using a fluoroenzyme immunoassay (Immuno CAP-FEIA) on the ImmunoCAP platform. (Phadia Thermo-Fisher Scientific, Uppsala, Sweden)

\section{Statistical analysis}

Data was analyzed using SPSS (IBM Corp. Released 2013. IBM SPSS Statistics for Windows, Version 22.0. Armonk, NY: IBM Corp). Data was checked for outliers, skew and kurtosis. Missing data were treated as 'missing at random'. Four outliers were found and when removed skew and kurtosis were within acceptable levels for a normal distribution $(<1.5)$. Data were analyzed with and without outliers and results were the same. Therefore, outliers were included in the dataset to ensure representativeness of the data. The relationships between acute serum tryptase and age and acute serum tryptase and time from symptom onset to sampling were analyzed using a Pearson's correlation. Differences in mean acute serum tryptase levels across groups were analyzed using independent samples t-tests. Where 
homogeneity of variance was significantly different (through inspection of the Levene's test), the corrected 't value' and degrees of freedom (df) were used. Due to the large number of t-tests run, alpha was set at 0.01 . All tests were two-tailed. A forced entry multiple regression model was run to investigate predictors of acute serum tryptase. All predictor variables that were significantly related to acute serum tryptase were included in the model. A logistic regression was also run to look at variables that might predict risk of high acute serum tryptase levels. Figures were constructed using GraphPad Prism version 5.00 for Windows, GraphPad Software, San Diego California USA. The ROC curve was constructed from the acute serum tryptase measurements from the anaphylaxis group and nonanaphylaxis control group using Prism GraphPad 5.00. Sensitivity, specificity, positive predictive values (PPV) and negative predictive values (NPV) were calculated at the $25^{\text {th }}, 50^{\text {th }}$ and $75^{\text {th }}$ centiles of acute serum tryptase measurements in the anaphylaxis group.

\section{Data storage and institutional approval}

To ensure data protection, data was stored on a physically and digitally secured computer at Birmingham Heartlands Hospital. The Microsoft Excel document was encrypted and all patient identifiable information was removed prior to analysis. The project was reviewed by the Research and Development Department (in HEFT) who verified that formal ethical approval was not required and then registered with the Clinical Governance Unit. The project required no external funding. 
197

198

199

200

201

202

203

204

205

206

\section{7}

208

209

210

211

212

213

214

215

216

217

218

219

220

221

\section{Results}

\section{Study population}

The study algorithm is summarized in Figure 1. Of 426 attendances, 141 (33.1\%) had an acute serum tryptase measurement. Demographics of the study sample are summarized in Table 1 and for the entire cohort in a recent publication by the authors along with extensive epidemiological analysis. (8) In our cohort of 426 patients, $105(24.6 \%)$ were children ( $<16$ years) and of these children only 6/105 (5.7\%) had a measurement of acute serum tryptase. In children $86 \%$ of reactions were attributed to food and current British guidelines recommend acute serum tryptase measurement in children only in cases of drug-induced, venom-induced or idiopathic anaphylaxis. (8) The mean age of the group who had acute serum tryptase measured is higher than the group that did not.

\section{Clinical manifestations}

44/141 (31.2\%) patients had cardiovascular symptoms or signs, of which $15(10.6 \%)$ had hypotension. $126(89.3 \%)$ had respiratory involvement with 41 (29.1\%) having objective evidence of bronchospasm and $9(6.4 \%)$ evidence of hypoxia. $140(99.3 \%)$ had skin or mucosal involvement, 42 (29.8\%) generalized urticaria, and 87 (61.7\%) angioedema. 35 (24.8\%) had gastrointestinal involvement.

\section{Acute serum tryptase}

Mean acute serum tryptase in the anaphylaxis group was $10.3 \mathrm{ng} / \mathrm{ml}(\mathrm{SD} \pm 10.4)$. In the control group of 25 patients mean acute serum tryptase was $6.8 \mathrm{ng} / \mathrm{ml}[\mathrm{SD} \pm 5.9])(\mathrm{t}=1.65 \mathrm{df}=164[\mathrm{p}=0.10])$. In the anaphylaxis group, acute serum tryptase was raised at or above $11.4 \mathrm{ng} / \mathrm{ml}$ (a previously accepted 'cutoff') in $46(32.6 \%)$ cases. In the control group, $3 / 25(12.0 \%)$ had an acute serum tryptase $\geq 11.4 \mathrm{ng} / \mathrm{ml}$. $132 / 141(93.6 \%$ had a recorded time of sampling on the electronic system. Of these, the mean time to the first acute serum tryptase measurement from onset of symptoms was 4 hours and 42 minutes ( $\mathrm{SD} \pm$ 05:03 hours). There was a weak negative correlation between acute serum tryptase level and time between symptom onset to sampling (Pearson correlation coefficient $-0.19[\mathrm{p}=0.026]$ ) (Figure S1). There was no statistically significant difference in mean time of sampling in the severe and non-severe 
anaphylaxis groups $(\mathrm{t}=1.13 \mathrm{df}=133[\mathrm{p}=0.26])$ and no statistically significant difference in mean time of sampling across different etiologies. No patients had serial measurements of acute serum tryptase.

23/141 (16.3\%) patients had a baseline serum tryptase more than 24 hours after symptom onset although none of these measurements were raised ( $\geq 11.4 \mathrm{ng} / \mathrm{ml}$ ). The median difference (delta) between acute serum tryptase and baseline tryptase was $115.9 \%$ (IQR 26.5 to 238.2). Delta was greater than the previously quoted cut-off of $135 \%$ (11) for $9 / 23(39.1 \%)$ cases. $13 / 45(28.9 \%)$ patients with an acute serum tryptase $\geq 11.4$ had a baseline tryptase measurement and $4 / 21(19.0 \%)$ patients with acute serum tryptase $\geq 20$ had a baseline tryptase measurement. All the patients with baseline measurements were seen in the clinic. There was a statistically significant difference between mean baseline serum tryptase and acute serum tryptase in the group with severe anaphylaxis $(\mathrm{n}=10$, baseline $4.6 \mathrm{ng} / \mathrm{ml}(\mathrm{SD} \pm 1.3) \mathrm{vs}$ acute serum tryptase $19.6 \mathrm{ng} / \mathrm{ml}(\mathrm{SD} \pm 16.4)$ (paired T-test: $\mathrm{t}=2.921 \mathrm{df}=9[\mathrm{p}=0.017])$ with a smaller, non-significant difference in the non-severe anaphylaxis group $(\mathrm{n}=13$, baseline $5.1 \mathrm{ng} / \mathrm{ml}(\mathrm{SD} \pm 2.0)$, acute serum tryptase $9.4 \mathrm{ng} / \mathrm{ml}(\mathrm{SD} \pm 4.9)(\mathrm{t}=2.032 \mathrm{df}=12[\mathrm{p}=0.065])$. Only one patient in the control group had a measure of baseline serum tryptase.

A mast cell disorder is considered in the differential diagnosis for all patients with spontaneous (idiopathic) anaphylaxis. Our clinical service considers a dermatology referral if cutaneous mastocytosis is suspected and the patient is also referred to a hematology clinic for consideration of bone marrow studies if the baseline serum tryptase is $\geq 20 \mathrm{ng} / \mathrm{ml}$. In the whole dataset (those who presented to ED with anaphylaxis regardless of their attendance in the allergy clinic), 13/45 (28.9\%) patients with an acute serum tryptase $\geq 11.4 \mathrm{ng} / \mathrm{ml}$ and $4 / 21(19.0 \%)$ patients with an acute serum tryptase $\geq 20 \mathrm{ng} / \mathrm{ml}$ had a baseline tryptase measurement. Following completion of the study, we wrote to the family physicians of all those patients with a raised acute serum tryptase $(>11.4 \mathrm{ng} / \mathrm{ml})$ and no record of baseline tryptase measurement to request that this be checked and that the report is brought to the attention of the allergy department if the baseline value is $\geq 11.4 \mathrm{ng} / \mathrm{ml}$, so a diagnosis of an underlying mast cell disorder could be considered. These additional measurements were not included in the study analysis. 


\section{Etiology of anaphylaxis}

$24976(53.9 \%)$ patients with an acute serum tryptase measurement were reviewed in person by an allergy

250

251

252

253

254

255

256

257

258

259

260

261

262

263

264

265

266

267

268

269

270

271 specialist in the secondary care clinic (in HEFT) for a comprehensive clinical evaluation and for further investigations as deemed necessary. All investigations were complete at the time of record review by the authors. Idiopathic anaphylaxis was the most common etiology (45/76 cases [59\%]) and was twice as common in females as in males $\left(35 / 49[71.4 \%]\right.$ vs. $10 / 27[37 \%]$ respectively $\left(\chi^{2}=7.16, \mathrm{df}=1\right.$ $[\mathrm{p}=0.008])$. There were $11(14.5 \%)$ cases of food-induced anaphylaxis. In this group, mean acute serum tryptase was $13.7(\mathrm{SD} \pm 10.6)$ with $6 / 11(15.5 \%)$ patients having an acute serum tryptase $\geq 11.4 \mathrm{ng} / \mathrm{ml}$ and 3/11 (27.3\%) having an acute serum tryptase $\geq 20 \mathrm{ng} / \mathrm{ml}$. There were $15(19.7 \%)$ cases of druginduced anaphylaxis. In this group, mean acute serum tryptase was $12.6 \mathrm{ng} / / \mathrm{ml}(\mathrm{SD} \pm 15.2)$ with $5 / 15$ (33.3\%) patients having an acute serum tryptase $\geq 11.4 \mathrm{ng} / \mathrm{ml}$ and $2 / 15(13.3 \%)$ having an acute serum tryptase $\geq 20 \mathrm{ng} / \mathrm{ml}$. There were $45(59.2 \%)$ cases of idiopathic anaphylaxis. In this group, mean acute serum tryptase was $7.7 \mathrm{ng} / \mathrm{ml}(\mathrm{SD} \pm 8.3)$ with $8 / 45(17.8 \%)$ having an acute serum tryptase $\geq 11.4 \mathrm{ng} / \mathrm{ml}$ and $4 / 45(8.9 \%)$ having an acute serum tryptase $\geq 20 \mathrm{ng} / \mathrm{ml}$. Idiopathic anaphylaxis was associated with lower acute serum tryptase levels than anaphylaxis due to drugs and food combined (mean $7.6 \mathrm{ng} / \mathrm{ml}$ $[\mathrm{SD} \pm 8.2]$ vs. $13.2 \mathrm{ng} / \mathrm{ml}[\mathrm{SD} \pm 13.1](\mathrm{t}=2.26, \mathrm{df}=67[\mathrm{p}=0.027])$. After thorough evaluation, no patient with idiopathic anaphylaxis was subsequently found to have indolent mastocytosis. There were no cases of venom-induced anaphylaxis in patients that had a measurement of acute serum tryptase reflecting the low frequency of cases in our entire cohort of 426 cases. Further details regarding etiology of anaphylaxis in the entire cohort (regardless of acute serum tryptase measurement) can be found in our recent publication.(8)

\section{Children}

There were six children ( $<16$ years old) who had a measurement of tryptase. Details are summarized in Table 2. 
The ROC curve (Figure 2) was generated using acute serum tryptase levels in patients presenting with anaphylaxis and acute serum tryptase levels in controls as described in the previous section. Data is summarized in quartiles of acute serum tryptase in Table 3 . Higher levels of acute serum tryptase $\left(75^{\text {th }}\right.$ centile $\geq 12.4 \mathrm{ng} / \mathrm{ml})$ showed high specificity $(88.0 \%)$ and PPV (0.93) for anaphylaxis but showed poor sensitivity (27.8\%) and NPV (0.17).

Factors associated with higher acute serum tryptase:

Univariate analyses are summarized in Table S1. Acute serum tryptase was higher for patients with severe anaphylaxis as defined by the Brown grading system $(\mathrm{p}=0.006)$, those with hypotension $(\mathrm{p}=0.012)$, those with any cardiovascular symptoms $(\mathrm{p}=0.009)$, those who had not self-administered an epinephrine auto-injector $(\mathrm{p}=0.002)$ and male sex $(\mathrm{p}=0.001)$. These were entered into a forced entry multiple regression model. The model was significant $(\mathrm{F}=8.98(5,140), \mathrm{p}<0.001)$ and explained $25 \%$ of the variance $\left(\mathrm{R}^{2}=.25\right.$, adj $\left.\mathrm{R}^{2}=.22\right)$. Hypotension ( $\mathrm{t}$-value -3.32 [95\% CI -15.59 to -3.94$] \mathrm{p}=0.001$ ) and male sex (t-value -3.05 [95\% CI -8.33 to -1.77$] \mathrm{p}=0.003$ ) emerged as significant predictors of a higher acute serum tryptase level (Table 4). 42/141 (29.8\%) patients had a history of asthma but this was not associated with acute serum tryptase (Table S1).

\section{Predictors of high acute serum tryptase}

In order to see whether variables could be used to predict the likelihood of someone having a high or low acute serum tryptase level, a logistic regression model was constructed. We used a previously suggested acute serum tryptase of $\geq 11.4 \mathrm{ng} / \mathrm{ml}$ as a 'cut off' between 'raised' and 'not raised' acute serum tryptase as the outcome variable. Variables that were significantly related to acute serum tryptase levels were entered into the model. This model was again significant $\left(\chi^{2}=29.66, p<0.001\right)$ and explained between $19 \%$ and $27 \%$ of the variance. Male sex and the presence of hypotension again significantly predicted increased odds of high acute serum tryptase levels $(\mathrm{OR}=2.66$ for male sex, $\mathrm{OR}=7.08$ for hypotension [Table 4]). 


\section{Discussion}

298 This is the first study to investigate the sensitivity and specificity of acute serum tryptase in cases of

299

300

301

302

303

304

305

306

307

308

309

310

311

312

313

314

315

316

317

318

319

320

321

322

323 anaphylaxis presenting to the ED. It also offers an insight into the real world ED scenario and how these conditions can influence the utility of such a test.

Anaphylaxis is a clinical diagnosis requiring prompt treatment and acute serum tryptase clearly does not constitute a part of the acute evaluation and management as results are not available to ED clinicians. Current British guidelines recommend three serial timed measurements of tryptase (1) and notably in our cohort this was not met in any patient. Whilst the relatively short timescale between the publication of these guidelines to our study could be cited as a potential reason for poor adherence, previous UK Resuscitation Council guidelines (2008) also recommended serial tryptase measurements in the same manner. (12) Multiple factors contribute to poor adherence: staff knowledge, a busy clinical environment, a 'four-hour wait target' where $95 \%$ of patients must be reviewed, diagnosed, treated and either discharged or admitted within four hours, and early discharge or transfer of patients. Acute serum tryptase results take several days to become available and thus are not available to ED clinicians who do not therefore see the benefits of the test. Many patients with milder cases of anaphylaxis do not require intravenous access or other blood tests and acute serum tryptase measurement is therefore a low priority task which adds to the workload of an already stretched team.

The time point of acute serum tryptase measurement (mean 4 hours 42 minutes [SD \pm 05:03 hours]) was such that the peak rise may have been missed in some cases. This however reflects a 'real world' clinical scenario since the timing of the acute serum tryptase sample depends on multiple factors including the rapidity of onset of symptoms, when the patient actually presents to ED, how long it takes to stabilize the patient before the admitting physician is able to obtain a sample for acute serum tryptase and other confounding practical variables as stated above. However, Stone et al. reported that although the acute serum tryptase peaks at 2-3 hours post-exposure, levels can, in some patients, remain elevated at $50 \%$ above baseline for up to 10 hours. (3) Previous studies have shown improved sensitivity of acute serum tryptase when serial measurements are taken (13-15) but clearly in a busy clinical environment this may be challenging given the 'four hour wait target' in the UK NHS as described above. 
324 Wongkaewpothong et al. (15) and Brown et al. (16) have reported considerably better sensitivity and 325 specificity than our study at a lower acute serum tryptase levels (50\% and $85 \%$ respectively at $3.0 \mathrm{ng} / \mathrm{ml}$ and $55 \%$ and $93 \%$ at $9.0 \mathrm{ng} / \mathrm{ml}$ respectively) however these were in the context of allergen challenge or immunotherapy where factors such as timing of the sample and definitive diagnosis of anaphylaxis can optimize the test. Previous ED based studies of acute serum tryptase measurement have not addressed the sensitivity and specificity of the test. $(3,5-7,17)$ Here we have for the first-time constructed ROC curves and generated sensitivity, specificity, PPV and NPV in a 'real world' ED setting. Using a 'cutoff' of $12.4 \mathrm{ng} / \mathrm{ml}\left(75^{\text {th }}\right.$ centile), we show a sensitivity of $27.8 \%$, specificity of $88 \%$ and PPV and NPV of 0.93 and 0.17 respectively indicating that acute serum tryptase measurement performs much more poorly in the ED environment. However, with a high specificity, when the acute serum tryptase is raised, it is highly likely that the patient has experienced anaphylaxis. Previously, it has been reported that a $\geq 135 \%$ rise (from baseline) in acute serum tryptase is a better predictor of anaphylaxis than an absolute measurement alone. (11) However, this was only seen in 39\% of cases in our study. In our anaphylaxis cohort, only 23/141 (16.3\%) patients had a baseline serum tryptase measurement (and only one in the control group), so we were unable to construct ROC curves for a percentage change from baseline. Only $28.9 \%$ of patients with an acute serum tryptase $\geq 11.4 \mathrm{ng} / \mathrm{ml}$ and $19.0 \%$ of patients with an acute serum tryptase $\geq 20 \mathrm{ng} / \mathrm{ml}$ had a baseline serum tryptase measurement. Mast cell disorders are considered for all patients with idiopathic anaphylaxis and are investigated and referred appropriately as described above.

We explored the factors that predict high acute serum tryptase levels using multiple and logistic regression models. A forced multiple regression model indicated that the presence of hypotension and male sex were the two factors that significantly predicted a higher acute serum tryptase. This finding was supported with a logistic regression analysis showing that male sex and presence of hypotension significantly increase the probability of having levels of acute serum tryptase over the 'cut-off' of $\geq 11.4 \mathrm{ng} / \mathrm{ml}$. The association with hypotension is a finding that is in keeping with previously published data. (3,5-6) However, the observation that patients with hypotension are seven times more likely to have a raised acute serum tryptase has not been reported previously (Table 4). Thus hypotension is a 
sensitive marker for an elevated acute serum tryptase. The strong association of severe hypotension and

352 higher acute serum tryptase is further supported by the high levels seen in patients developing severe cardiovascular perioperative anaphylaxis during general anesthesia, recently reported by our group (18) and Mertes et al. (19)

The novel finding that male sex predicts higher acute serum tryptase warrants further investigation particularly as there is no known sex predisposition with respect to severity. Higher baseline serum tryptase in males has been reported previously (20-22) which may at least in part explain this association. Also, rates of idiopathic anaphylaxis in our cohort were lower in males than females $(37.0 \%$ vs 71.4\%) and idiopathic anaphylaxis was associated with lower acute serum tryptase. Previous studies have reported that food-induced anaphylaxis does not lead to an elevated acute serum tryptase as often as other causes. $(7,23)$ However, in this study we found that food-induced anaphylaxis leads to an elevated acute serum tryptase as often as other causes. This may be related to relatively smaller sample size, wider confidence intervals as well as the fact that a major comparison group is idiopathic anaphylaxis. Our finding that use of an epinephrine auto-injector is associated with lower acute serum tryptase may highlight the importance of early administration of epinephrine in preventing a more severe systemic response to the allergen and thus preventing a rise in acute serum tryptase.

This study has limitations. Firstly, we had a relatively small sample size, although the total number of cases in our cohort exceeds previous studies. (3,5-7) Additionally, only about a third of patients presenting with anaphylaxis had a measurement of acute serum tryptase introducing selection bias although we have shown that among adults in our study, characteristics between groups are broadly similar although there is a trend towards more severe cases of anaphylaxis being included. The relatively small sample size is compounded by the low rates of requests for baseline tryptase measurement. Secondly, this was a retrospective study but all cases were carefully reviewed with respect to ED and ambulance crew observations and the sampling time for acute serum tryptase was recorded accurately. Thirdly, the control group that we used was small (25 patients). In the absence of a better control group the use of this group of patients was a pragmatic choice, as patients with non-allergic conditions do not have routine acute serum tryptase measurements. These patients had mucocutaneous findings only and 
therefore did not meet the WAO criteria for anaphylaxis, although it is plausible that treatment may have prevented some of them developing anaphylaxis.

The role of acute serum tryptase measurement in cases of suspected anaphylaxis remains debated despite being recommended in British and other national and international guidelines. (1-2) Acute serum tryptase measurement performs substantially better in the more controlled environments of allergen challenge and immunotherapy $(15,24)$ than it did in our study although an acute serum tryptase of $>12.4 \mathrm{ng} / \mathrm{ml}$ in ED patients does makes the diagnosis of anaphylaxis highly likely. The high specificity of acute serum tryptase at this 'cut off' and its strong association with hypotension makes it a useful test in specific circumstances to distinguish anaphylaxis from its 'mimics'. Also, it can be of use in patients presenting with isolated, severe hypotension (e.g. insect-sting induced anaphylaxis with hypotension alone, perioperative anaphylaxis, Kounis syndrome etc.) or in special groups such as the elderly, the visually impaired, those with a learning disability or in cases where there is paucity of historical or clinical information during assessment in an allergy clinic. Acute serum tryptase is of much less use in cases of sporadic anaphylaxis in otherwise normal patients where the clinical history yields the diagnosis. There is preliminary evidence supporting the role for newer biomarkers in anaphylaxis including chymase, carboxypeptidase and dipeptyl peptidase 1. (25-26) Further studies are required for investigating the clinical utility of these biomarkers in anaphylaxis.

In conclusion, our data has shown that acute serum tryptase has a high PPV and specificity, and low sensitivity and NPV in the diagnosis of anaphylaxis presenting to EDs of NHS hospitals in the UK. Hypotension and male sex were significant predictors of higher acute serum tryptase and there is a suggestion that the use of an epinephrine auto-injector can prevent a rise in acute serum tryptase. Furthermore, there was poor compliance with British guidelines with respect to serial acute serum tryptase measurement in the three EDs included in this study. Serial acute serum tryptase measurements may be impractical in the vast majority of cases of anaphylaxis which are seen, diagnosed, treated and discharged from the ED within four hours. 


\section{Acknowledgements}

405 The authors would like to thank Ms. J. Flowers of the Heart of England NHS Foundation Trust

406 Emergency Department, Birmingham, UK for performing the electronic database search.

407 
1. National Institute for Health and Clinical Excellence guideline (2011). Anaphylaxis: assessment and referral after emergency treatment. NICE guideline (CG134)

2. Campbell RL, Li JTC, Nicklas RA, Sadosty AT. Emergency department diagnosis and treatment of anaphylaxis: A practice parameter. Ann Allergy, Asthma Immunol. 2014;113(6):599-608.

3. Stone SF, Cotterell C, Isbister GK, Holdgate A, Brown SGA. Elevated serum cytokines during human anaphylaxis: Identification of potential mediators of acute allergic reactions. J Allergy Clin Immunol. 2009;124(4):786-92.e4.

4. Lemon-Mulé H, Nowak-Wegrzyn A, Berin C, Knight AK. Pathophysiology of food-induced anaphylaxis. Curr Allergy Asthma Rep. 2008;8(3):201-8.

5. Lin RY, Schwartz LB, Curry A, Pesola GR, Knight RJ, Lee HS, et al. Histamine and tryptase levels in patients with acute allergic reactions: An emergency department-based study. J Allergy Clin Immunol. 2000;106(1 Pt 1):65-71.

6. Vadas P, Perelman B, Liss G. Platelet-activating factor, histamine, and tryptase levels in human anaphylaxis. J Allergy Clin Immunol. 2013;131(1):144-9.

7. Sala-Cunill A, Cardona V, Labrador-Horrillo M, Luengo O, Esteso O, Garriga T, et al. Usefulness and limitations of sequential serum tryptase for the diagnosis of anaphylaxis in 102 patients. Int Arch Allergy Immunol. 2013;160(2):192-9.

8. Buka RJ, Crossman RJ, Melchior CL, Huissoon AP, Hackett S, Dorrian S, et al. Anaphylaxis and ethnicity: higher incidence in British South Asians. Allergy. 2015;27;70(12):1580-7.

9. Simons FE, Ardusso LR, Bilo MB, El-Gamal YM, Ledford DK, Ring J, et al. World allergy organization guidelines for the assessment and management of anaphylaxis. World Allergy Organ J. 2011/02/01 ed. 2011;4(2):13-37.

10. Brown AF, McKinnon D, Chu K. Emergency department anaphylaxis: A review of 142 patients in a single year. J Allergy Clin Immunol. 2001;108(5):861-6.

11. Borer-Reinhold M, Haeberli G, Bitzenhofer M, Jandus P, Hausmann O, Fricker M, et al. An increase in serum tryptase even below $11.4 \mathrm{ng} / \mathrm{mL}$ may indicate a mast cell-mediated hypersensitivity reaction: a prospective study in Hymenoptera venom allergic patients. Clin Exp Allergy. 2011;41(12):1777-83.

12. Soar J, Pumphrey R, Cant A, Clarke S, Corbett A, Dawson P, et al. Emergency treatment of anaphylactic reactions - Guidelines for healthcare providers. Resuscitation. 2008;77(2):15769.

13. Schwartz LB, Yunginger JW, Miller J, Bokhari R, Dull D. Time course of appearance and disappearance of human mast cell tryptase in the circulation after anaphylaxis. J Clin Invest. 1989;83(5):1551-5.

14. Schwartz LB. Diagnostic value of tryptase in anaphylaxis and mastocytosis. Immunol Allergy Clin North Am. 2006;26(3):451-63.

15. Wongkaewpothong P, Pacharn P, Sripramong C, Boonchoo S, Piboonpocanun S, Visitsunthorn N, et al. The utility of serum tryptase in the diagnosis of food-induced anaphylaxis. Allergy Asthma Immunol Res. 2014;6(4):304-9.

16. Braganza SC, Acworth JP, Mckinnon DRL, Peake JE, Brown AFT. Paediatric emergency department anaphylaxis: different patterns from adults. Arch Dis Child. 2006;91(2):159-63.

17. De Schryver S, Halbrich M, Clarke A, La Vieille S, Eisman H, Alizadehfar R, et al. Tryptase levels in children presenting with anaphylaxis: Temporal trends and associated factors. J Allergy Clin Immunol. 2016;137(4):1138-42.

18. Krishna MT, York M, Chin T, Gnanakumaran G, Heslegrave J, Derbridge C, et al. Multicentre retrospective analysis of anaphylaxis during general anaesthesia in the United 
Kingdom: aetiology and diagnostic performance of acute serum tryptase. Clin Exp Immunol. 2014;178(2):399-404.

19. Mertes PM, Laxenaire M-C, Alla F. Anaphylactic and anaphylactoid reactions occurring during anesthesia in France in 1999-2000. Anesthesiology. 2003;99(3):536-45.

20. Sirvent AE, González C, Enríquez R, Fernández J, Millán I, Barber X, et al. Serum tryptase levels and markers of renal dysfunction in a population with chronic kidney disease. $\mathrm{J}$ Nephrol. 2010;23(3):282-90.

21. Komarow HD, Hu Z, Brittain E, Uzzaman A, Gaskins D, Metcalfe DD. Serum tryptase levels in atopic and nonatopic children. J Allergy Clin Immunol. 2009;124(4):845-8.

22. Carballada F, Alonso M, Vizcaino L, Coutinho V, Núñez R, Vidal C, et al. Serum tryptase concentrations in beekeepers with and without Hymenoptera venom allergy. J Investig Allergol Clin Immunol. 2013;23(1):30-6.

23. Sampson HA, Mendelson L, Rosen JP. Fatal and near-fatal anaphylactic reactions to food in children and adolescents. N Engl J Med. 1992;327(6):380-4.

24. Brown SGA, Blackman KE, Heddle RJ. Can serum mast cell tryptase help diagnose anaphylaxis? Emerg Med Australas. 2004;16(2):120-4.

25. Whitworth HS, Zhou XY, Lau L, Bodey K, Erlewyn-Lajeunesse M, Millinchamp F, et al. Dipeptidyl Peptidase I as a Serum Marker of Allergic Reactions to Food. J Allergy Clin Immunol. 2011;127(2):AB71-AB71.

26. Brown TA, Whitworth HS, Zhou XY, Lau L, Eren E, Walls AF. Mast Cell Carboxypeptidase as a Confirmatory and Predictive Marker in Allergic Reactions to Drugs. J Allergy Clin Immunol.; 2011;127(2):AB143-AB143. 
481 Figure 1: Study algorithm. 3516 attendances to the ED during 2012 were identified using an electronic

482

483

484

485

486

487

488

489

490

491

492

493

494

495

496

497

498

499

500

501

502 search of the attendances database using wide search terms. 426 attendances fulfilled the WAO diagnostic criteria for anaphylaxis. 141 patients had a measurement of acute serum tryptase, and 23 of these had a baseline tryptase measurement. 76 were followed up in the allergy clinic.

Figure 2. Receiver operating characteristic (ROC) curve. ROC curve showing acute serum tryptase measurements in patients with anaphylaxis vs control group (patients not fulfilling the WAO diagnostic criteria for anaphylaxis). Area: $0.58,95 \%$ CI $0.47-0.69, \mathrm{p}=0.19$. Table 3 shows sensitivity, specificity, negative predictive value (NPV) and positive predictive value (PPV) for acute serum tryptase at different 'cut-offs'.

\section{Figure S1. Correlation between acute serum tryptase measurement and time from symptom onset}

to sampling. There is a weak negative correlation between acute serum tryptase level and time between symptom onset to sampling. Pearson correlation coefficient $-0.19(\mathrm{p}=0.026) . \mathrm{N}=132(9$ did not have recorded timings).

5

6

7


503 Accompanying tables:

504

505 Anaphylaxis and Clinical Utility of Real World Measurement of Acute Serum Tryptase in UK

506 Emergency Departments

$507 \quad$ Buka et al.

508 
509 Table 1. Demographics of the study population

\begin{tabular}{|c|c|c|c|c|}
\hline & $\underline{\text { AT measured }}$ & $\begin{array}{c}\text { AT not } \\
\text { measured }\end{array}$ & $\underline{\text { Total }}$ & p-value \\
\hline Number of cases of anaphylaxis & $\underline{141(33.1 \%)}$ & $\underline{285(66.9 \%)}$ & $\underline{426}$ & \\
\hline Number of severe cases* & $\underline{56(39.7 \%)}$ & $\underline{89(31.2 \%)}$ & $145(34.0 \%)$ & $\underline{0.08}$ \\
\hline \multicolumn{5}{|l|}{$\underline{\operatorname{Sex}}$} \\
\hline$\underline{\text { Males }}$ & $\underline{55(39.0 \%)}$ & $\underline{116(40.7 \%)}$ & $\underline{171(40.1 \%)}$ & \multirow{2}{*}{$\underline{0.75}$} \\
\hline Females & $\underline{86(61.0 \%)}$ & $\underline{169(59.3 \%)}$ & $\underline{255(59.9 \%)}$ & \\
\hline$\underline{\text { Mean age }}$ & $\begin{array}{c}\underline{40.4} \\
(\mathrm{SD} \pm 20.2) \\
\end{array}$ & $\begin{array}{c}\underline{26.7} \\
(\mathrm{SD} \pm 21.4)\end{array}$ & $\begin{array}{c}\underline{31.3} \\
(\mathrm{SD} \pm 22.0)\end{array}$ & $\leq 0.001$ \\
\hline Mean age of adults (those $\geq 16 y$ ) & $\begin{array}{c}\underline{41.7} \\
(\mathrm{SD} \pm 19.5)\end{array}$ & $\begin{array}{c}\underline{38.4} \\
(\mathrm{SD} \pm 17.9)\end{array}$ & $\begin{array}{c}\underline{39.8} \\
(\mathrm{SD} \pm 18.7)\end{array}$ & $\underline{0.12}$ \\
\hline Patients with asthma & $\underline{43(30.4 \%)}$ & $\underline{78(27.4 \%)}$ & $\underline{121(28.4 \%)}$ & $\underline{0.57}$ \\
\hline
\end{tabular}

*Brown severity grading (10) 
512 Table 2. Children (<16 years old) with anaphylaxis and acute serum tryptase measurements. 2/6

$513 \quad(33.3 \%)$ children had AT $\geq 11.4 \mathrm{ng} / \mathrm{ml}$. None had a measurement of baseline tryptase available at the

514 time of the study. None had hypotension or other evidence of cardiovascular compromise.

\begin{tabular}{|c|c|c|c|c|c|}
\hline Age & $\underline{\text { Sex }}$ & $\begin{array}{c}\text { Severity } \\
\text { (Brown grading) }\end{array}$ & $\begin{array}{l}\text { Treated with } \\
\text { epinephrine }\end{array}$ & AT (ng/ml) & $\frac{\text { Causative }}{\underline{\text { factor }}}$ \\
\hline$\underline{5}$ & Male & $\underline{\text { Severe }}$ & $\underline{\text { Yes }}$ & $\underline{35.5}$ & Nuts \\
\hline$\underline{6}$ & $\underline{\text { Male }}$ & $\underline{\text { Severe }}$ & $\underline{\text { Yes }}$ & $\underline{6.05}$ & $\underline{\text { Milk }}$ \\
\hline$\underline{10}$ & Female & $\underline{\text { Severe }}$ & $\underline{\text { Yes }}$ & $\underline{3.82}$ & $\underline{\text { Nuts }}$ \\
\hline$\underline{11}$ & $\underline{\text { Female }}$ & Not severe & No & $\underline{5.85}$ & $\underline{\text { Cat }}$ \\
\hline$\underline{12}$ & $\underline{\text { Male }}$ & $\underline{\text { Not severe }}$ & $\underline{\text { Yes }}$ & $\underline{5.24}$ & Nuts \\
\hline$\underline{12}$ & $\underline{\text { Male }}$ & Not severe & $\underline{\text { Yes }}$ & $\underline{12.1}$ & $\underline{\text { Nuts }}$ \\
\hline Mean: 9.3 & & & & Median: 5.95 & \\
\hline
\end{tabular}

515

516 
517 Table 3. Table associated with Figure 2 showing sensitivity, specificity, negative predictive value

519 (NPV) and positive predictive value (PPV) for AT at different 'cut-offs' according to ROC analysis.

\begin{tabular}{|c|c|c|c|c|c|c|}
\hline \multirow[b]{2}{*}{ 75th centile } & \multicolumn{6}{|c|}{ Tryptase cut-off: $12.4 \mathrm{ng} / \mathrm{ml}$} \\
\hline & $\underline{\text { Anaphylaxis }}$ & $\underline{\text { Non-anaphylaxis }}$ & $\underline{\text { PPV }}$ & $\underline{\text { NPV }}$ & $\frac{\text { Sensitivity }}{(\%)}$ & $\frac{\text { Specificity }}{(\%)}$ \\
\hline $\begin{array}{l}\text { Tryptase raised } \\
\text { Tryptase not raised }\end{array}$ & $\underline{38}$ & $\underline{3}$ & $\underline{0.93}$ & $\underline{0.17}$ & $\underline{27.8}$ & $\underline{88.0}$ \\
\hline$\underline{\text { 50th centile }}$ & $\begin{array}{l}\text { Tryptase cut } \\
\text { Anaphylaxis }\end{array}$ & $\begin{array}{l}\text { off: } 5.4 \mathrm{ng} / \mathrm{ml} \\
\text { Non-anaphylaxis }\end{array}$ & $\underline{\mathrm{PPV}}$ & $\underline{\mathrm{NPV}}$ & $\frac{\text { Sensitivity }}{(\%)}$ & $\frac{\text { Specificity }}{(\%)}$ \\
\hline $\begin{array}{l}\text { Tryptase raised } \\
\text { Tryptase not raised }\end{array}$ & $\underline{72}$ & $\begin{array}{r}\underline{9} \\
\underline{16} \\
\end{array}$ & $\underline{0.89}$ & $\underline{0.19}$ & $\underline{50.7}$ & $\underline{64.0}$ \\
\hline 25th centile & $\begin{array}{l}\text { Tryptase cut } \\
\underline{\text { Anaphylaxis }}\end{array}$ & $\begin{array}{l}\text { off: } 3.8 \mathrm{ng} / \mathrm{ml} \\
\text { Non-anaphylaxis }\end{array}$ & $\underline{\text { PPV }}$ & $\underline{\text { NPV }}$ & $\frac{\text { Sensitivity }}{(\%)}$ & $\frac{\text { Specificity }}{(\%)}$ \\
\hline $\begin{array}{l}\text { Tryptase raised } \\
\text { Tryptase not raised }\end{array}$ & $\frac{107}{35}$ & $\frac{18}{7}$ & $\underline{0.86}$ & $\underline{0.17}$ & $\underline{75.4}$ & $\underline{28.0}$ \\
\hline
\end{tabular}

521

522

523

524

525 
526 Table 4. Logistic regression analysis showing predictors of acute tryptase.

\begin{tabular}{|c|c|c|c|c|c|c|}
\hline \multirow[t]{2}{*}{$\underline{\text { Predictors }}$} & \multirow[t]{2}{*}{$\frac{\text { Standard }}{\underline{\text { Error }}}$} & \multirow[t]{2}{*}{$\underline{\text { Wald test }}$} & \multirow[t]{2}{*}{ p-value } & \multirow[t]{2}{*}{$\underline{\operatorname{Exp}(B)}$} & \multicolumn{2}{|c|}{$\frac{95 \% \text { Confidence }}{\underline{\text { Intervals }}}$} \\
\hline & & & & & Lower & Upper \\
\hline$\underline{\text { Sex (male) }}$ & .41 & $\underline{5.64}$ & .02 & $\underline{2.66}$ & $\underline{1.19}$ & $\underline{5.95}$ \\
\hline Cardiovascular & .56 & .70 & .79 & $\underline{1.16}$ & .39 & $\underline{3.44}$ \\
\hline Hypotension & .81 & $\underline{5.91}$ & .01 & $\underline{7.08}$ & 1.46 & $\underline{34.33}$ \\
\hline Brown Grading & .49 & $\underline{1.72}$ & .19 & .53 & .20 & $\underline{1.37}$ \\
\hline$\underline{\text { Use of AAI* }}$ & $\underline{1.16}$ & $\underline{1.90}$ & .17 & .20 & .02 & $\underline{1.96}$ \\
\hline
\end{tabular}

528 *Adrenaline auto-injector

529 Cox and Snell R2 $=.190$

$530 \quad$ Nagelkerke R2 $=.265$

$531 \quad-2 \log$ likelihood $=148.42$

532

533 Statistically significant p-values are given in bold 
544 Table S1. Univariate analysis: means (standard deviations) of AT levels across clinical characteristics

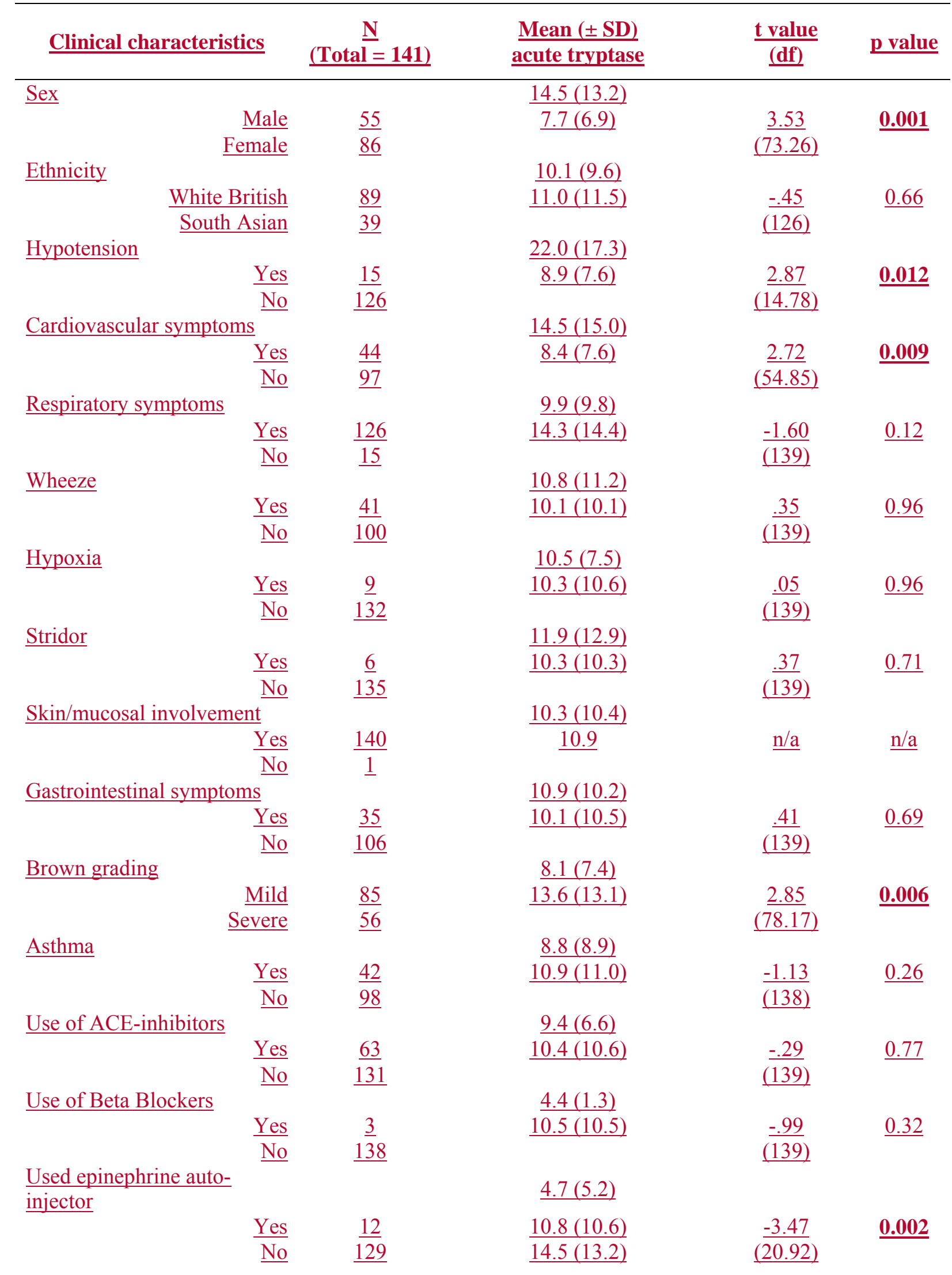


Table 3 continued

\begin{tabular}{|c|c|c|c|c|}
\hline$\underline{\text { Clinical characteristics }}$ & $\stackrel{\underline{N}}{(\text { Total }=141)}$ & $\frac{\text { Mean }( \pm \text { SD) }}{\text { acute tryptase }}$ & $\frac{\text { t-value }}{\underline{\text { (df) }}}$ & $p$ value \\
\hline \multicolumn{5}{|l|}{ Administered epinephrine } \\
\hline$\underline{\text { Yes }}$ & $\underline{82}$ & $\underline{10.9(11.6)}$ & .77 & $\underline{0.45}$ \\
\hline No & $\underline{59}$ & $9.5(8.5)$ & $(139)$ & \\
\hline \multicolumn{5}{|l|}{ Administered $2^{\text {nd }}$ epinephrine } \\
\hline$\underline{\text { Yes }}$ & $\underline{21}$ & $\underline{8.5(8.5)}$ & $\underline{-.85}$ & $\underline{0.40}$ \\
\hline$\underline{\underline{\text { No }}}$ & $\underline{120}$ & $10.6(10.7)$ & $(139)$ & \\
\hline \multicolumn{5}{|l|}{ Needed intravenous fluid } \\
\hline No & $\underline{37}$ & $12.3(12.2)$ & $\underline{1.36}$ & $\underline{0.18}$ \\
\hline$\underline{\mathrm{Yes}}$ & 104 & $9.6(9.6)$ & $(139)$ & \\
\hline
\end{tabular}

546

$547 \quad$ Statistically significant $p$ values are given in bold 
Accompanying figures:

565 Anaphylaxis and Clinical Utility of Real World Measurement of Acute Serum Tryptase in UK

$566 \quad$ Emergency Departments

567 Buka et al.

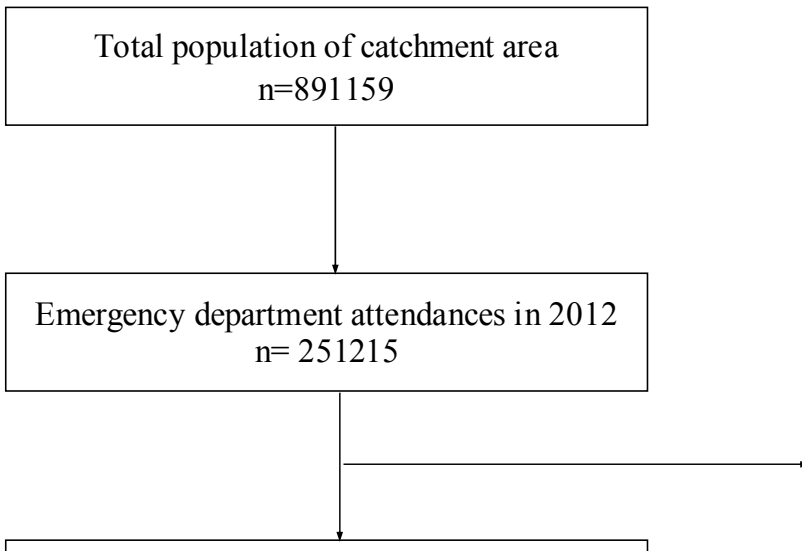

Excluded by search $n=247699$

Attendances identified by search $\mathrm{n}=3516$

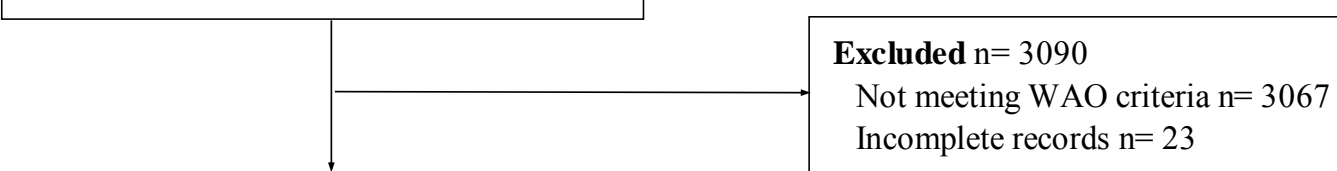

Attendances fulfilling WAO criteria $n=426$

Acute serum tryptase not measured $n=285$

Acute serum tryptase measured $n=141$

Baseline tryptase measured $n=23$ 


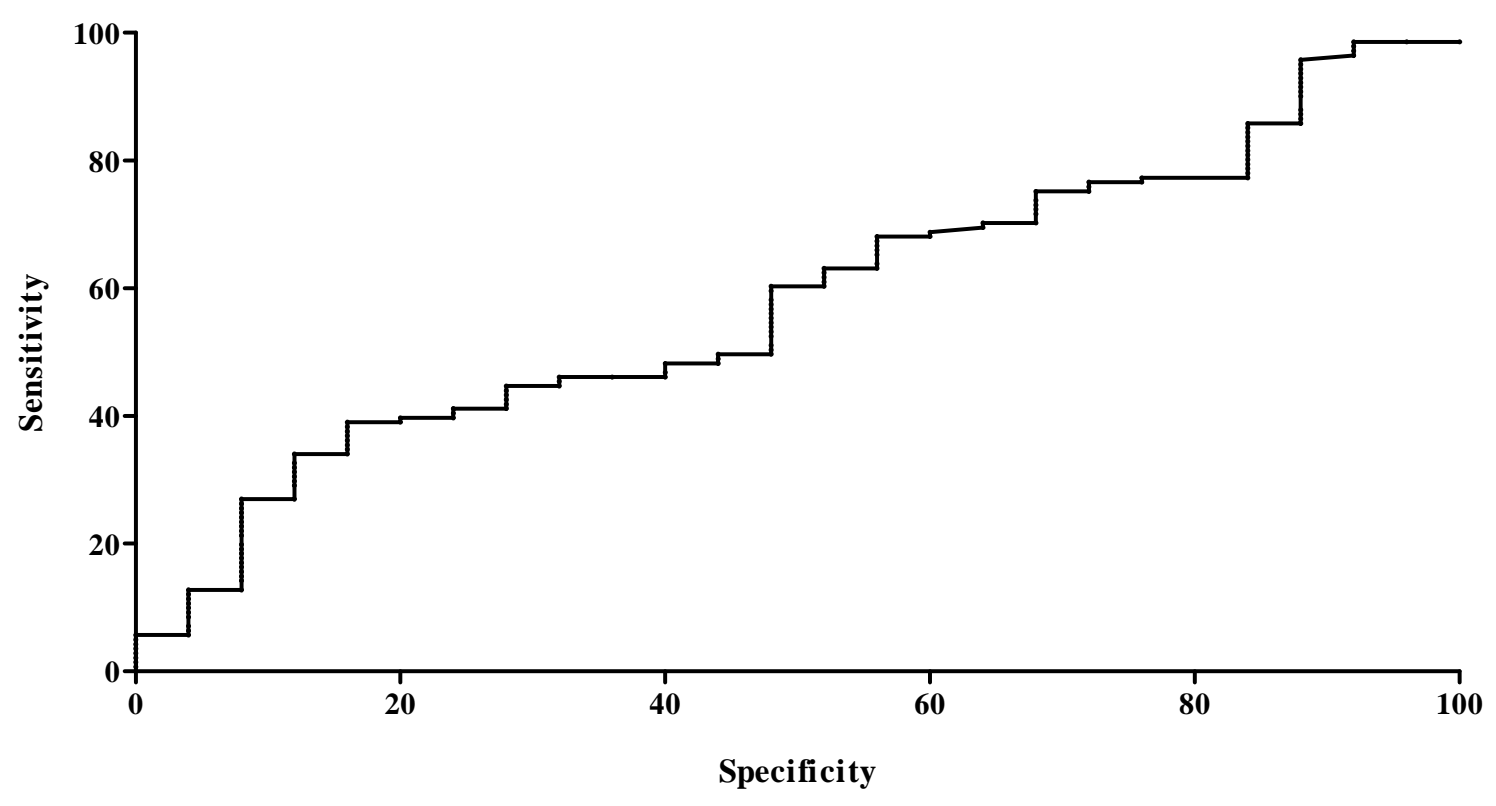

569

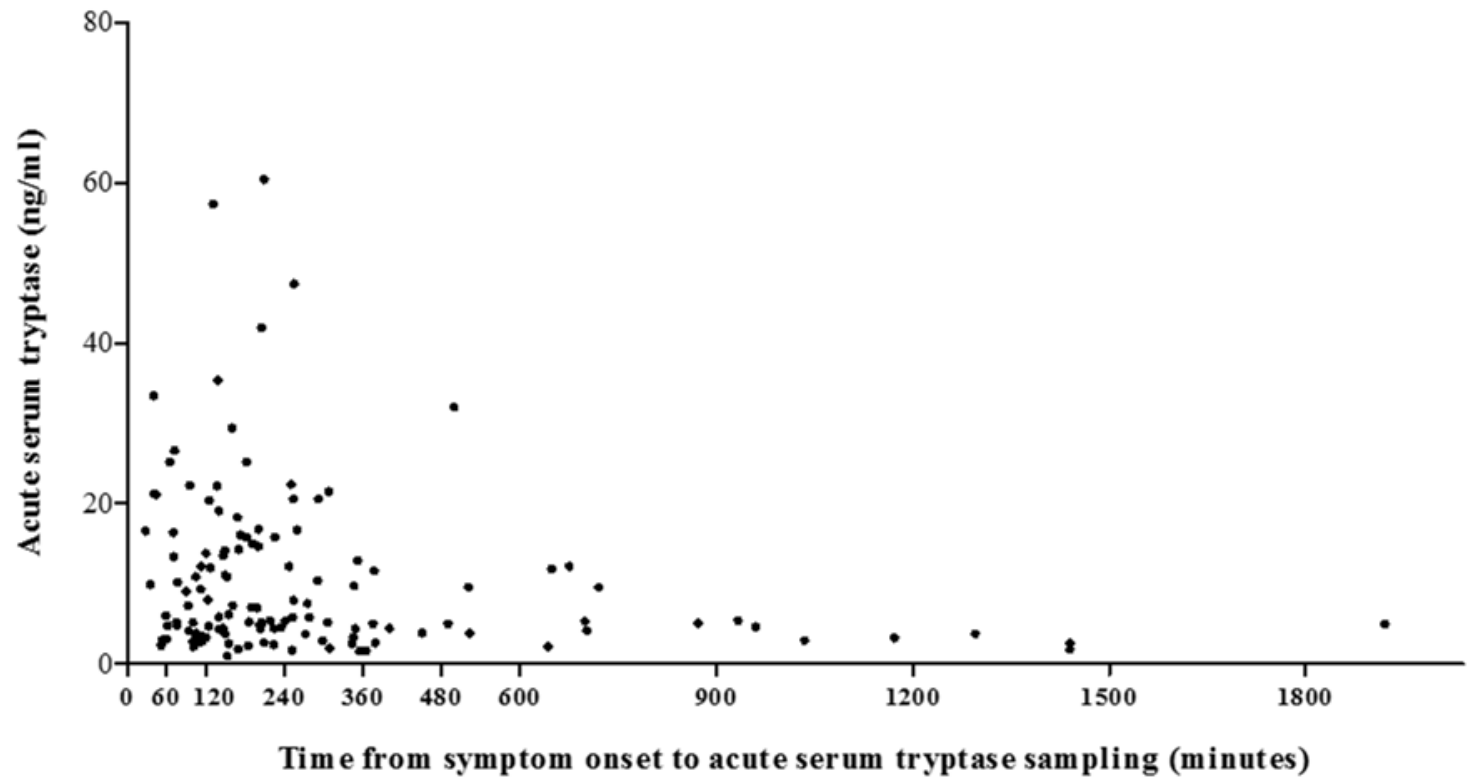

